\title{
Designing a Nano Infrastructure for Brazil's Amazon Water Resources: A Quadruple Helix Approach
}

\author{
Raul Gouvea \\ Anderson School of Management, University of New Mexico, Albuquerque, USA \\ Email: rauldg@unm.edu \\ Received 4 January 2015; accepted 24 January 2015; published 27 January 2015 \\ Copyright @ 2015 by author and Scientific Research Publishing Inc. \\ This work is licensed under the Creative Commons Attribution International License (CC BY). \\ http://creativecommons.org/licenses/by/4.0/ \\ (c) (i) Open Access
}

\begin{abstract}
This paper elaborates on the role of green technologies and innovations in "greening" Brazil's Amazon region fresh water resources. The paper elaborates on the development of an innovation quadruple helix to better manage the region's water resources. Brazil accounts for close to $12 \%$ of the earth's fresh water reserves, while most of it is in the Amazon region. The preservation of water reserves on a global scale is of paramount importance in the $21^{\text {st }}$ century. Brazil, however, has not managed its water resources effectively leading to the increasing pollution and contamination of its Amazonian water resources.
\end{abstract}

\section{Keywords}

Brazil, Amazon, Sustainability, Nanotechnologies

\section{Introduction}

Designing a green economy for the $21^{\text {st }}$ century is the challenge facing many nations around the globe. The increasing demand for economic growth and development needs to be balanced by a focus on sustainability, inclusiveness and equitability. The "business-as-usual" approach no longer satisfies the demands of a new paradigm of economic growth and development. The three major dimensions of sustainability (environment, social, and economic) need to be in consideration when transitioning to a green economy. The shift will also entail a new paradigm in production and consumption. The green economy also dictates less stress on natural resources by supporting the development of greener production processes, innovations and technologies [1]-[3].

Brazil's Amazon region holds one of the world's richest reservoirs of fresh water. However, increasing urbanization, manufacturing, deforestation, and mining are placing Brazil's Amazon region fresh water reserves at 
risk. In addition, global climate change is stressing the Amazon ecosystem. Thus, Brazil's Amazon region transition from a brown to a greener economy will have to take into account the creation of strategies to safeguard its fresh water reserves and ecosystems [4] [5].

Greening growth and development strategies may mitigate some of the risks permeating climate change and address Millennium Development goals. Fresh water is one of the pillars of the Green Economy initiative and it permeates any global discussions related to sustainability strategies. With the global population increasing in size and becoming more urbanized, more people in emerging economies are achieving higher levels of income; the demand for water consumption per capita is expected to rise [6] [7].

More than ever, Brazil needs to address the different dimensions of its Green Fresh Water Helix, i.e., safety, quality, security, and availability. These four dimensions need to be carefully assessed and policies and strategies need to be designed and implemented to guarantee the long-term and short-term sustainability of water resources in one of the planet's most important sources of fresh water [8].

Further discussion is needed on the implementation of a greener water strategy in the Amazon region, bringing together the local government, private sector, academia research centers, and the local civil society. This quadruple helix approach also calls for the introduction of green technologies and innovations in the Amazon region to further protect and understand the water dimension of Brazil's Amazon region. More precisely, this paper stresses the role of green nanotechnologies in promoting and fostering the protection of the Amazon region's ecosystem, and the further economic utilization of its fresh water potential. The Amazon region may become one of the world's largest exporter of fresh water, however the proper care and understanding of its specificities is of paramount importance to unleash the economic benefits of greening fresh water Amazon business environment. The implementation of greener water strategies for the Brazilian Amazon region has dramatic implications not only for the Brazilian economy but also for the whole global economy since Brazil's Amazon region is one of the world's most important and richest reservoir of fresh water in the planet [9].

\section{Brazil’s Amazon Region}

Globalization forces allied to increasing economic growth and development in emerging economies are putting additional stress on the world's fresh water reserves [10]-[12]. The preservations and sustainability of Brazil's Amazon fresh water comes into play when one considers that the global economy is under increasing water stress. Several nations are already undertaking increasing proactive water management programs, predicting increasing water shortages in the near future. Several factors are contributing to this state of affairs:

a) Climate change and its implications to precipitation patterns

b) Increasing pollution of fresh water sources

c) Increasing global population and related impacts on food production with consequent increase in water for crop irrigation

d) Increasing urbanization trends globally, resulting in substantial increases of water consumption.

Thus, more than ever the four dimensions of "green water quadruple helix" (security, safety, quality, and availability) need to be addressed by policy-makers in order to face the increasing pressure in a sustainable fashion. It is crucial that measures to integrate a national water management and resource development program be implemented in Brazil's economic strategy. In addition, the protection of Brazil's water resources is vital for the implementation of a green-based equitable economy and society in Brazil. In this fashion, water technologies and innovations play a key role in providing solutions to these pressing water issues.

\subsection{Water Quality Monitoring}

Continuous Water quality monitoring is becoming of critical importance for emerging economies such as China, Taiwan and India. China is implementing as part of its $11^{\text {th }}$ Five Year Plan a modern environmental water monitoring system. In India, a network of online monitoring stations is being deployed along the Ganges River. Taiwan is also installing real time monitoring systems around the nation to safeguard its water resources [13] [14]. The United Nations Environmental Program, Global Environment Monitoring System (GEMS) water program aims at building and gathering data and knowledge about the water quality on a global scale [15].

In line with the Millennium Ecosystem assessment, Brazil needs to develop monitoring systems in order to provide a critical assessment of Brazil's Amazon region. The nexus environment, economy, and society needs to be mapped and assessed to better protect, maintain, and restore Brazil's fresh water resources and the Amazon 
ecosystem.

The implementation of a network of sensors in the rivers of Brazil's Amazon region is imperative. Designing an Amazon River water monitoring and alert system is very important for the region. Geographic Information systems (GIS) and a sensor web can develop synergies allowing policy-makers and researchers to implement sound environmental policies in the region [16].

It is vital that Amazon Rivers are monitored continuously and in real time, not by the current system that is sporadic and relatively non-effective. River pollution is a major problem in Brazil's Amazon region, which could be improved by nano water quality monitoring systems that can be developed to allow for the assessment of water quality parameters in real-time. The biggest advantage of this technology is that it will allow for the rapid response to pollution spills, and reliable information to create and enact conservation policies.

\subsection{Water Customs}

An integrated Amazon River basin trans-boundary management system needs to be developed involving neighboring countries that share the same rivers with Brazil. "Water customs" with sensors and monitoring equipment would allow Brazilian researchers and policymakers to analyze the types of pollutants resulting from the waters flowing from these countries into Brazil. That should make the identification of these foreign sources of pollutants easier to address if these countries are members of this integrated monitoring system. For instance, several cities such as Benjamin Constant, in the state of Amazonas along the Solimoes River suffer from pollution originating in Colombia and Peru. It is vital for the sustainability of the Solimoes River to develop "water customs” in order to assess the pollutants that are coming from neighboring countries. With this there can be a cooperative to develop joint trans-border strategies, which would implement strategies to curb pollution and restore the quality of the river. In 2014, hospital waste and domestic waste from the district of Yavari in Peru were being tossed in the Solimoes River compromising the safety of the water in Peru and in Brazil [17].

\subsection{Nano Sensors}

It is clear that there is an urgent need to deploy nano sensors and Instruments in several regions of the Amazon basin that could measure the quality of the water in real-time and better assess the risks and threats. In addition to monitoring, this system could assist in designing reactive and pro-active policies and strategies, to safeguard the sustainability of the Amazon region water resources.

There are many different ways in which technology can be leveraged to provide the best information and allow for meaningful efforts to maintain the quality of water. For example, wireless autonomous units using solar power would allow for remote monitoring and real time data collection which would greatly improve water management strategies and policies in Brazil's Amazon region. For instance the use of online sensors and bio-monitors in the city of Manaus can be used to assess the pollution resulting from its manufacturing pole. This type of system, which has been used in South Korea and China, would certainly provide a better understanding of the threats permeating the Amazon region's fresh water reserves [18]. The city of Manaus hosts more than 500 multinationals manufacturing and assembling from electronic products to motorcycles. A monitoring system could assess the impact of these companies on the rivers around the city of Manaus [19] [20].

The development of monitoring tools, hardware and software would improve the regions understanding of the major threats surrounding its water resources [21] [22]. Real time monitoring would improve the Amazon region's hygienic safety; such a system is not yet available in the Amazon region. The addition of wireless sensor technologies would allow for real time, continuous reading of several sub-regions of the region. Thus providing a better assessment of the regions fresh water resources [23].

The deployment of nano sensors throughout the Amazon River basin will expand the role of nanotechnology in assessing the Amazon's region ecosystem distress. The increasing accuracy and sensitivity of nano sensors along with the vast capacity of these sensors to "read" biochemical, biological and chemical analysis offers many capabilities to policy-makers and researchers engaged in environmental policy-making, research, and management of natural resources. Electronic circuit miniature and MEMS are allowing for the development of micro sensor nodes that allow for the integration of a number of sensors, wireless communication and CPU further expanding the use of sensor networks and environmental monitoring [24].

Sensors measuring water quality and safety rely on indicators such as; biological oxygen demand (BOD), chemical oxygen demand (COD), total organic carbon (TOC), pH, and oxidation reduction potential (ORP). 
These measures define the quality of water and wastewater. For instance, anthropogenic mercury emissions related to artisanal and small-scale gold mining operations are of major concern in the Amazon region. In rivers, inorganic mercury changes into methyl mercury deeply contaminating fish stocks and contaminating the humans who eat these fish products along with other water mammals. Mercury has contaminated thousands of people in the Amazon region, a major health threat to the region. In addition to gold mining, manufacturing activities, deforestation, power plants, waste disposal, and landfills are contributing to the increasing presence of Mercury in Amazon Rivers [25].

The planning and implementation of a new approach to water resource management in the Amazon region will need to involve the four dimensions of a green helix initiative: a) government, b) universities and research centers, c) private sector, and d) non-governmental organizations (NGOs).

In the state of Amazonas, the state's planning agency (SEPLAN), the Fundacao de Amparo a Pesquisa do Estado do Amazonas (FAPEAM), and the state's environmental agency (SDS), have developed pro-active sustainable strategies, mostly directed towards the state of Amazonas forest resources. Their participation in funding water related projects and programs would be very important. The attraction of venture capitalists is also of paramount importance. Brazil's VC's environment, however, is still nascent and the large majority of VCs are targeting Brazil's consumer facing sectors, with only a handful paying heed to technology investment innovation [26].

The creation of a "Water Technology and Innovation Center" could foster a number of water innovation and research related programs in the state of Amazonas [27]. Local research centers and Universities, such as the “Instituto Nacional de Pesquisas da Amazonia (INPA), Centro de Biotecnologia da Amazonia (CBA), UniversidadeEstadual do Amazonas (UEA), and the Federal University of Amazonas (UFAM) have developed a number of water related research agendas, but in a non-coordinated fashion. Local research foundations such as the Fundacao Centro de Analises, Pesquisa e InovacaoTecnologica-FUCAPI, could also play an important role acting as a conduit in the commercialization of technologies and innovations developed locally. Local NGOS, such as Fundacao Amazonas Sustentavel (FAS) have developed a solid network throughout the Amazon region. Its main focus has been on implementing "Reducing Emissions from Deforestation and Forest Degradation (REDD)" programs. In addition their state-wide network with indigenous and ribeirinhos groups would be extremely important in developing a stakeholder strategy towards the protection of the state of Amazonas water resources. The state's industrial pole (PIM) houses more than 500 firms, many of them multinational companies. Their participation via collaboration in water monitoring programs would be vital for the feasibility and successful implementation of the monitoring system. In 2013, PIM firms grossed US \$38.5 billion in revenues employing 125,000 workers.

\section{A Green Water Quadruple Helix}

The creation of a water nano innovation quadruple helix, in its purpose to bring government agencies, academic and research institutions, private sector, and NGOs together is of extreme importance in the implementation of a new innovation water resource agenda mindset in the Amazon region. This paper expands on traditional approaches to innovation, such as the implementation of triple helix arrangements, by adding a green perspective and by adding consumers to the innovation dimension, thus creating a quadruple green helix approach [28]-[31].

In addition as shown in Figure 1, the implementation of a Quadruple Green Helix in Brazil's Amazon region demands a green mindset that incorporates:

1) Consumers demanding green products, services, and innovation

2) Government designing policies and strategies to foster the development of a green and sustainable society and economy

3) The private sector via the development of technologies and innovations that will result in green products and services

4) The academic and research institutions through the development of green research agendas.

The Water Quadruple Helix and the Green Quadruple Helix interface and through synergies reinforce the establishment and implementation of green and sustainable agendas.

Co-operation with federal level agencies such as the Inter-ministerial Nanotechnology Committee (CIN) will be of extreme importance in the development of a local water nano innovation quadruple helix in the Amazon region. As of 2014, Brazil’s National System of Nanotechnology had not developed any nano laboratories in the 
The quadruple Green Helix

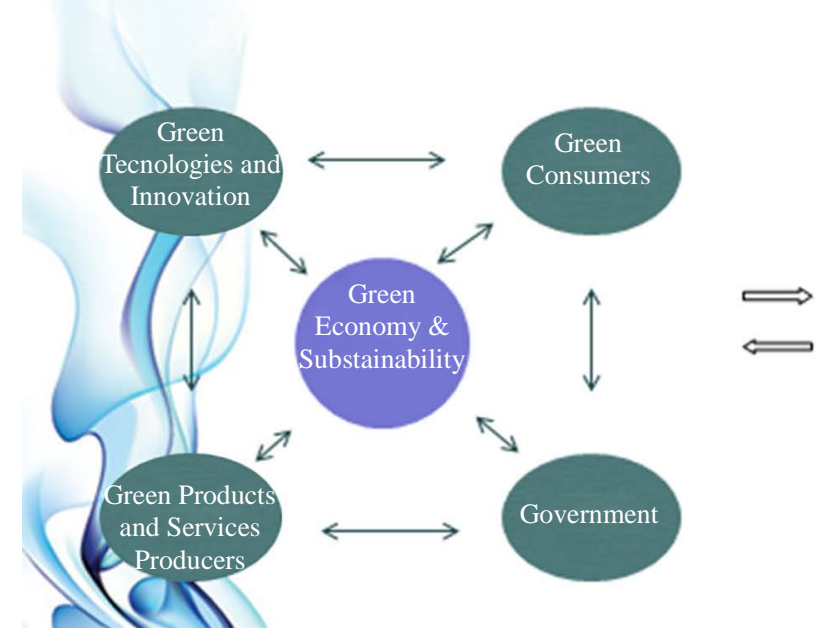

\section{Green Water Helix}

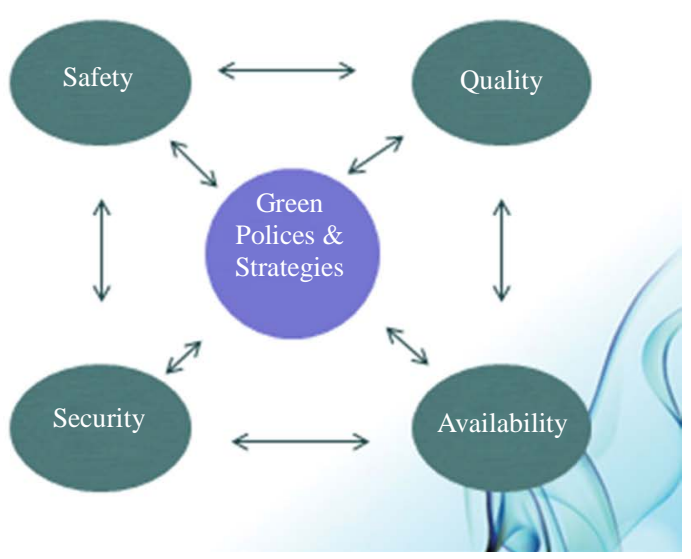

Figure 1. The quadruple green helix. Source: elaborated by the author.

state of Amazonas. In addition, there is not a clear reference to water resources under the SisNano key areas of interest. There is a reference to "environment" and "health", but nothing specific for water resources, yet there are specific references for oil \& gas [32].

It is also important to engage in the development of international research cooperation agreements. The development of indigenous nano technologies and innovations applied to water resources is very important for the development of a nano commons in Brazil. However, it is also important to develop cross-national research agendas with other nations and research institutions that are developing nanotechnologies and innovations related to water resources.

\section{Final Remarks}

Nanotechnology has extensive applications in environmental mitigation [33]. One of the objectives of Green nanotechnologies is to produce nano products that offer potential solutions to environmental issues. Nano products have direct applications such as nano sensors and remediation uses [34]. Nanotechnology can be leveraged to address environmental issues and challenges. The synergy between nanotechnology and green chemistry and green engineering can address a number of current environmental problems facing ecosystems under threat such as Brazil's Amazon region [35]. Thus, nano technologies offer the possibility of designing green processes and products to allow companies and governments to develop proactive and reactive sustainable strategies and solutions.

Nanotechnology also holds the potential to protect ecosystems via assessment and remediation of pollutants and development and creation of new green technologies [36]. In addition, nano sensors can allow policy-makers to develop warning systems and provide remediation solutions.

Brazil needs to implement water quality monitoring systems that would allow policy-makers and researchers to access information on the safety of Amazon Rivers as well as information on security related issues permeating its rivers and lakes. With the adoption and implementation of these technologies and innovations, the national safety of Brazil's population and preservation of water resources can be greatly increased and plans can be created to prevent widespread outbreaks of dangerous pathogens. Not only is Brazil's human safety a concern but also their economic health can only be boosted with innovative new water technologies and innovations.

\section{References}

[1] UN (1987) Our Common Future. United Nations, New York.

[2] UNEP (2012) Measuring Water Use in a Green Economy. www.unep.org

[3] UNEP (2013) Building Inclusive Green Economies: Success Stories from South-South Cooperation. www.unep.org 
[4] Johnsson, R. (2014) Brazil Water Leaning Series: Gestao de Recursos Hidricos no Brasil: Desafios e Novas Perspectivas. www.worldbank.org

[5] Val, A., et al. (2014) Amazonia: Recursos Hidricos e Sustentabilidade. www.abc.org.br

[6] Chellaney, B. (2014) Asia’s Water Wars. World Policy Journal, 30, 9-11.

[7] Institute for European Environmental Policy (2012) Nature and Its Role in the Transition to a Green Economy. www.eeep.eu

[8] Gouvea, R., Kassicieh, S. and Montoya, M. (2012) Designing Competitive Strategies in a Green Economy. Technological Forecasting and Social Change, 80, 221-230.

[9] Gouvea, R. (2011) Recursos Hidricos \& Economia Verde: Criando Vantagens Competitivas. WITS Conference, Manaus.

[10] UN (2013a) Water in a Green Economy. www.un.org

[11] Viana, V. (2010) Sustainable Development in Practice: Lessons Learned from Amazonas. International Institute for Environment and Development, London.

[12] Gouvea, R. (1998) Floods of Fortune: Sustainable Business Strategies in the Brazilian Amazon Region. Latin American Business Review, 1, 97-117. http://dx.doi.org/10.1300/J140v01n02_06

[13] Envirotech-Online (2013) Water Pollution in Asia-A Brief Review of Monitoring Technologies. http://envirotech-online.com

[14] Karn, B. (2006) Can Nanotechnology Be Green? National Institute for Material Science, NIMS, Tokyo.

[15] UN (2013) United Nations Environment Programme. Global Environment Monitoring System (GEMS) Water Program. United Nations, New York.

[16] Markovic, N., Stanimirovic, A. and Stoimenov, L. (2009) Sensor Web for River Water Pollution Monitoring and Alert System. 12th AGILE International Conference on Geographic Information Science, Leibniz Universitat, Hannover, 1-9.

[17] Gomes, E. (2014) Lixo Descartadoem Braco do Rio Javari por Comunidade Peruana Coloca Municipiodo AMem Risco. A Critica, 6 de Fevereiro. www.acritica.com.br

[18] EPA (2007) A Review of Emerging Sensor Technologies for Facilitating Long-Term Ground Water Monitoring of Volatile Organic Compounds. EPA, Washington DC.

[19] Oliveira, A. and Machado, J. (2009) The Manaus Industrial Pole and its Dynamics. In: Rivas, A., et al., Eds., Economic Instruments to Protect the Amazon: The Manaus Industrial Pole Experience, Editora CRV, Curitiba, 31-49.

[20] Suframa (2014) Manaus Industrial Sector. www.suframa.gov.br

[21] Walsh, S. (2012) Let Failure be your Guide: Becoming a Relevant Researcher for Industrial Renewal. Inaugural Lecture, Universiteit Twente, Enschede.

[22] Gunatilaka, A., Moscetta, P. and Sanfilippo, L. (2012) Recent Advancements in Water Quality Monitoring-The Use of Miniaturized Sensors and Novel Analytical Measuring Techniques for in Situ and On-Line Real Time Measurements. www.mendedreality.com

[23] Roseline, R., Devapriya, M. and Sumathi, P. (2013) Pollution Monitoring Using Sensors and Wireless Sensor Networks: A Survey. International Journal of Application or Innovation in Engineering \& Management, 2, 119-124.

[24] Mangematin, V. and Walsh, S. (2012) The Future of Nanotechnologies. Technovation, 32, 157-160. http://dx.doi.org/10.1016/j.technovation.2012.01.003

[25] UNEP (2013b) Global Mercury Assessment 2013. UNEP, Geneva.

[26] Gouvea, R. and Kassicieh, S. (2012) Bridging the Innovation Divide: The Brazilian Experience. Thunderbird International Business Review, 54, 275-289. http://dx.doi.org/10.1002/tie.21461

[27] Gouvea, R. and Kassicieh, S. (2010) Building an Eco-Innovation Cluster: Water Cluster in the Brazilian Amazon Region. International Journal of Social Ecology and Sustainable Development, 1, 27-39. http://dx.doi.org/10.4018/jsesd.2010040103

[28] Leydesdorff, L. (2012) The Triple Helix of University-Industry-Government Relations. Mimeo, University of Amsterdam, Amsterdam.

[29] Ronga, M. and Etzkowitz, H. (2013) Triple Helix Systems: An Analytical Framework for Innovation Policy and Practice in the Knowledge Society. Industry and Higher Education, 27, 237-262. http://dx.doi.org/10.5367/ihe.2013.0165

[30] Mowery, D. and Sampat, B. (2014) Universities in Natural Innovation Systems. Mimeo, Hass School of Business, U.C. Berkeley, Berkeley.

[31] Groen, A. and Walsh, S. (2013) Introduction to the Field of Emerging Technology Management. Creativity and Inno- 
vation Management, 22, 1-5. http://dx.doi.org/10.1111/caim.12019

[32] Plentz, F. and Fazzio, A. (2013) Consideracoes sobre o Programa Brasileiro de Nanotecnologia. Ciência e Cultura, 65. http://cienciaecultura.bvs.br

[33] OECD (2013) Nanotechnology for Green Innovation. OECD Science, Technology and Industry Policy Papers, No. 5, OECD Publishing, Paris.

[34] Center for Community Innovation (2008) Defining the Green Economy: A Primer on Green Economic Development. Center for Community Innovation, Berkeley.

[35] Woodrow Wilson International Center for Scholars (2007) Nanotechnology Provides Green Path to Environmentally Sustainable Economy. Release No. 35-07, Woodrow Wilson International Center, Washington DC.

[36] NNCO—National Nanotechnology Coordination Office (2003) Nanotechnology and the Environment. www.nano.gov 
Scientific Research Publishing (SCIRP) is one of the largest Open Access journal publishers. It is currently publishing more than 200 open access, online, peer-reviewed journals covering a wide range of academic disciplines. SCIRP serves the worldwide academic communities and contributes to the progress and application of science with its publication.

Other selected journals from SCIRP are listed as below. Submit your manuscript to us via either submit@scirp.org or Online Submission Portal.
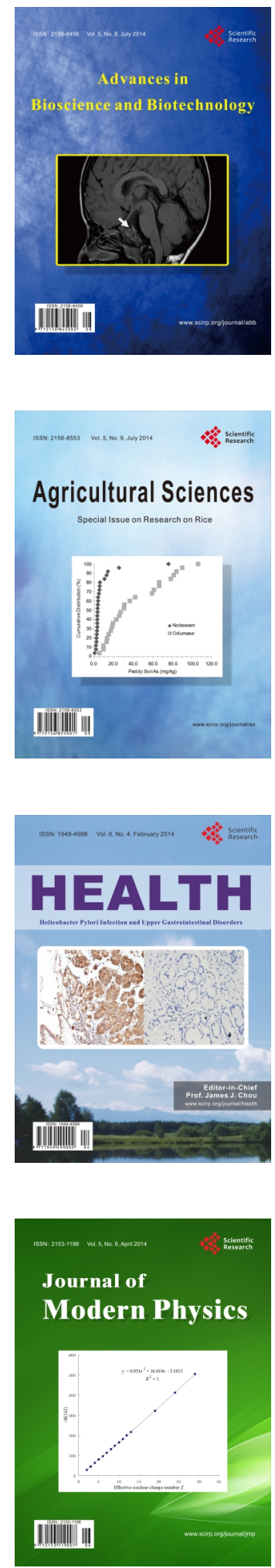
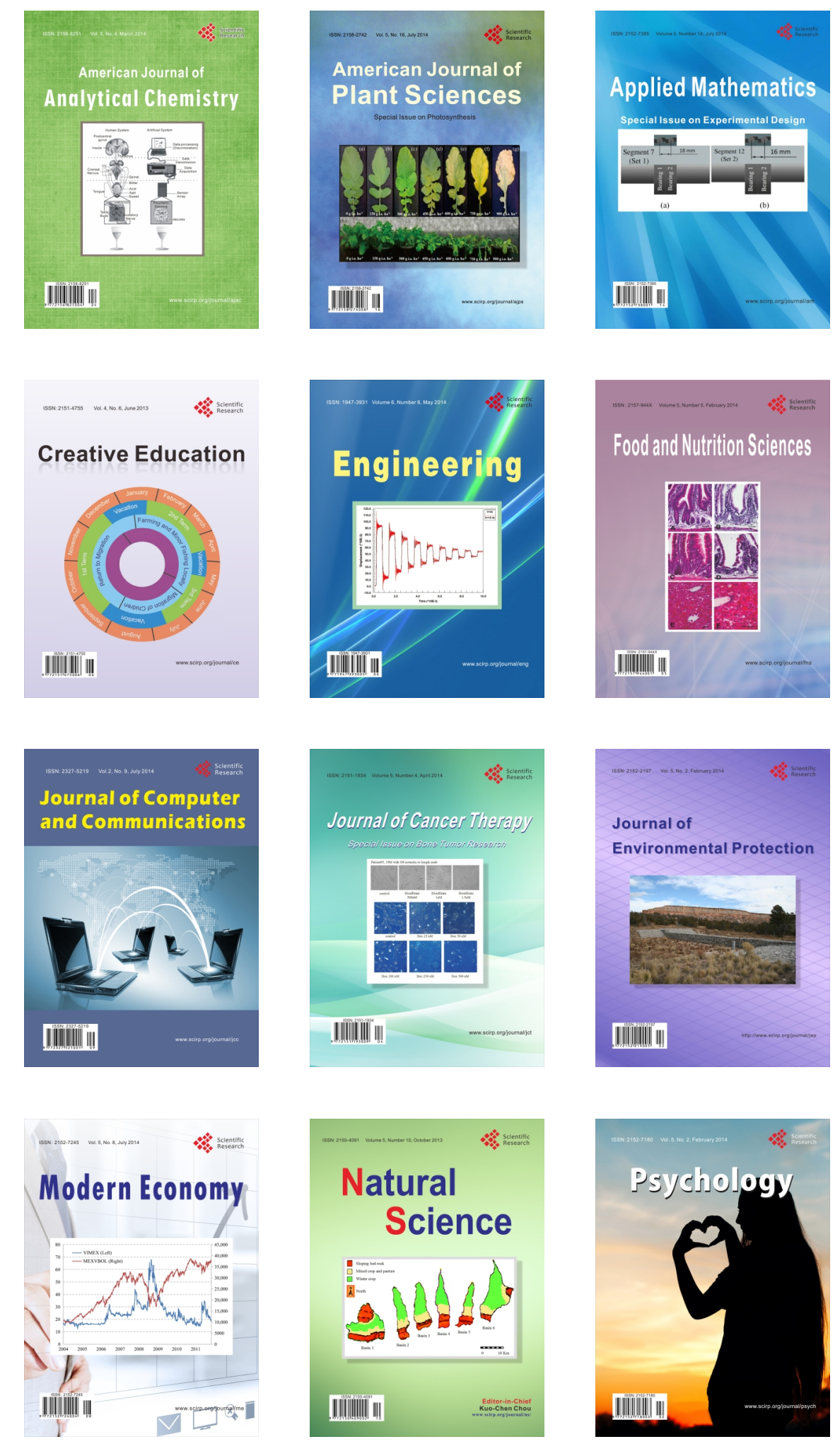